\title{
Minute Times mole Per Liter Per Milligram Per Gram Per Day
}

National Cancer Institute

\section{Source}

National Cancer Institute. Minute Times mole Per Liter Per Milligram Per Gram Per Day.

NCl Thesaurus. Code C117947.

Minute times mole per liter, divided by milligram per gram per day. 